\title{
EVALUATION OF STRONTIUM ALUMINATE PHOSPHORESCENT EFFECT ON BLOOD AS POTENTIAL LIGHT SOURCE FOR PHOTOTHERAPY
}

\author{
Heng Jie Choong, Nursakinah Suardi, Naser M. Ahmed \\ Universiti Sains Malaysia, School of Physics, 11800, Penang, Malaysia
}

\begin{abstract}
Phototherapy has shown its effect on cell stimulation and inhibition based on Arndt-Schulz model. Even though this therapeutic method has apparent effect, but it has limitations for epithelial application due to limitations on light penetration. Hence, with the ideology of fully overcoming this limitation, phosphorescent powder (strontium aluminate) is proposed as the potential light source that emitting photon from inside the body for phototherapy purposes. The strontium aluminate powder used in the experiment has the highest peak absorption at wavelength around $650 \mathrm{~nm}$ and lowest at around $350 \mathrm{~nm}$. According to FESEM images, the powder has the particle size varies from 10 to $50 \mu \mathrm{m}$ at cubic phase. The assessment is done by studying the effect on erythrocyte after blood plasma is irradiated by strontium aluminate powder's photon. The powder luminesces with a maximum at $491.5 \mathrm{~nm}$ when pumped with $473 \mathrm{~nm}$ laser at $100 \mathrm{~mW}$ in fixed amount of $0.005 \pm 0.001 \mathrm{~g}$. Later, it is mixed with centrifuged blood plasma for a predetermined time period $(5,10,15$, and 20 minutes). From this study, it shows that 5 minutes irradiation is the optimum period for erythrocyte in term of morphology enhancement and increase of UV-visible absorption spectrum with at least $21 \%$ in comparing with control blood. While the significant increment located at wavelengths $340 \mathrm{~nm}$ and $414 \mathrm{~nm}$ with both increased by $54 \%$ and $41 \%$, respectively. However, for 10 minutes and beyond, the irradiation leads to morphology deterioration while the UV-visible spectrum decrement starts at 15 minutes and beyond. In conjunction, a comparison between blood plasma that either interacted with powder emitting photon or powder with no emission shows that photon emission plays a role in the phototherapy effect.
\end{abstract}

Keywords: phototherapy, phosphorescent, red blood cells, UV-visible spectroscopy, self-illuminated, laser.

For citations: Heng Jie Choong, Nursakinah Suardi, Naser M. Ahmed. Evaluation of strontium aluminate phosphorescent effect on blood as potential light source for phototherapy, Biomedical Photonics, 2020, vol. 9, no 3, pp. 21-29. doi: 10.24931/2413-9432-2020-9-3-21-29

\section{ОЦЕНКА АЛЮМИНАТА СТРОНЦИЯ КАК ПОТЕНЦИАЛЬНОГО ИСТОЧНИКА СВЕТА ДЛЯ ФОТОТЕРАПИИ ПО ЕГО ФОСФОРЕСЦЕНТНОМУ ДЕЙСТВИЮ НА КРОВЬ}

\author{
Heng Jie Choong, Nursakinah Suardi, Naser M. Ahmed \\ Научный университет Малайзии, Малайзия
}

\section{Резюме}

Несмотря на доказанную эффективность фототерапии, у этого метода есть ограничения для эпителиального применения из-за незначительного проникновения света. Авторами предложен фосфоресцирующий порошок (алюминат стронция) в качестве потенциального источника света, излучающего фотоны изнутри тела для целей фототерапии. Порошок алюмината стронция, использованный в эксперименте, имеет самое высокое пиковое поглощение при длине волны около 650 нм и самое низкое при длине волны около 350 нм. Согласно изображениям автоэлектронной сканирующей микроскопии, порошок имеет размер частиц от 10 до 50 мкм в кубической фазе. Оценка эффективности фототерапии с предложенным соединением проведена путем изучения воздействия на эритроциты облученной порошком плазмы крови. Фосфоресценция порошка с фиксированный массой 0,005 \pm 0,001 г имеет максимум на длине волны 491,5 нм при накачке лазером с длиной волны 473 нм с мощностью 100 мВт. Затем его смешивают с центрифугированной плазмой крови в течение определенного периода времени (5, 10, 15 и 20 мин). Полученные результаты демонстрируют, что 5-минутное облучение является оптимальным периодом для эритроцитов с точки зрения улучшения морфологии и увеличения спектра поглощения УФ-видимой области по крайней мере на $21 \%$ по сравнению с контрольной кровью. При этом значительный прирост приходится на длины волн 340 нм и 414 нм, которые увеличиваются на 54\% и 41\% соответственно. Однако, для 10 мин и более облучение вызывает ухудшение морфологии, в то время как УФ-видимый спектр уменьшается начиная с 15 мин и позже. В связи с этим изучается сравнение плазмы крови, которая взаимодействовала с фосфоресцирующим порошком, с нефосфоресцирующим порошком, чтобы показать, что излучение играет роль в создании эффекта фототерапии. 
Ключевые слова: фототерапия, фосфоресценция, красные кровяные клетки, УФ-спектроскопия, аутофлуоресценция, лазер

Для цитирования: Heng Jie Choong, Nursakinah Suardi, Naser M. Ahmed. Оценка алюмината строция как потенциального источника света для фототерапии по его фосфоресцентному действию на кровь // Biomedical Photonics. - 2020. - Т. 9, № 3. - С. 21-29. doi: $10.24931 / 2413-9432-2020-9-3-21-29$

Контакты: Heng Jie Choong, e-mail: choonghengjie@yahoo.com

Nursakinah Suardi, e-mail: nsakinahsuardi@usm.my

\section{Introduction}

Phototherapy utilized light to conduct treatment with different light source and variation of parameters such as wavelength, irradiance, pulse structure, coherence, and polarization [1-3]. Initially, laser is widely used as it is thought that the monochromatic and coherence of laser would give extra benefit for treatment. This thought was no longer hold as similar effect is observed by using monochromatic light source like Light Emitting Diodes (LEDs) [4]. The respond of cells, either stimulation or inhibition, is depended on the output power of light which can be described through Arndt-Schulz curve and Arndt-Schulz model. The cells would be stimulated at certain threshold and inhibition is promoted beyond the threshold. From Arndt-Schulz model the parameters for the threshold are wavelength of light, irradiance of light, and the period of irradiation. The absolute Arndt-Schulz model is associated with parameters like wavelengths, tissue types, redox states, and different pulse parameters [3, 5-7].

Several experiments were conducted to observe the phototherapy effect by using different light sources while wavelength of light, irradiance, and exposure time remains the same. The results showed that similar effects can be observed even though different light sources were used [1, 2, 8]. Among the phototherapy treatment, phototherapy towards blood able to show significant effect. A study conducted by Siti Sakinah Mohd Fuad et al. showed that the RBCs of human blood would denature and forming echinocytes after irradiated by $589 \mathrm{~nm}$ yellow laser. The formation of echinocytes was caused by the loss of water and potassium, which decreases the generation of Adenosine Triphosphate (ATP). Concurrently, the RBCs' light absorption showed increment after irradiation for 10 minutes till 40 minutes. The decrement of absorbance was observed after the irradiation extended to 50 minutes and beyond. This corresponds to biphasic response of having two, either good or bad, reaction oxygen species (ROS). Mitochondrial would be stimulated on electron transport, which increases ATP production for good ROS. At the same time, the cell would signal and activate redox-sensitive transcription factors. On the contrary, bad ROS occur as the dose increases and lead to the damaging of mitochondria and apoptosis [9]. Another study conducted by Kujawa et al. demonstrated a visible effect on RBCs' ATPase activities and membrane structure after irradiated with near infrared $(810 \mathrm{~nm})$ laser. The irradiation-induced modulation of RBCs membrane which could change the activity of membrane ion pumps and ion flows [10]. The effect towards RBCs can be induced through blood plasma. Mustafa et al. conducted a study on erythrocyte sedimentation rate (EST) after irradiated with low-level laser. The study showed that effective reduction of ESR appeared after the irradiation of laser with a dose of $72 \mathrm{~J} / \mathrm{cm}^{2}$ at wavelength of $405 \mathrm{~nm}$. Besides, their study showed that whole blood ESR reduction is greatly reduced to less than $51 \%$ (from $15 \pm 3.7 \mathrm{~mm} / \mathrm{h}$ to $7.6 \pm 2.3 \mathrm{~mm} / \mathrm{h}$ ) in comparison between separated $\mathrm{RBC}$ s resuspended in irradiated plasma and separated RBCs resuspended in non-irradiated plasma. Hence, this study suggested that the whole blood ESR effect is mainly induced by the plasma composition [11].

Due to the limitation of light penetration towards the region of interest within the body, phototherapy has been limited for epithelial application. Attempts have been taken by introducing penetrating light in the red or near infrared range, for brain photobiomodulation to relieve brain disorders [12-16]. However, the penetration is still limited to a certain depth depending on the anatomical region. For instance, $808 \mathrm{~nm}$ light source has penetration to depth about $40 \mathrm{~mm}$ to $50 \mathrm{~mm}[14,17,18]$. Alternatively, intracranial method is an approach to overcome the limitation by directly deliver light to the brain with light-optical fiber device. However, this method is associated with risk as minimal surgical stereotactic procedure is needed to insert light-optical device within the brain [12].

Hence, in conjunction to overcome the limitation, it is proposed to use light source, like phosphorescent powder, that could emit light after traveling to the region of interest within the body itself. This paper is assessing phosphorescent powder (strontium aluminate) as the potential light source for phototherapy through in vitro blood phototherapy by irradiating blood plasma with RBCs morphology and absorbance spectrum being studied.

\section{Materials and Methods}

Characterization of strontium aluminate powder

The absorption of strontium aluminate was evaluated using UV-Visible spectrophotometer at the 
range of $200 \mathrm{~nm}$ to $800 \mathrm{~nm}$. Emission spectroscopy was used to evaluate the emission of strontium aluminate at the range of $380 \mathrm{~nm}$ to $780 \mathrm{~nm}$. XRD was performed in comparison with database compounds. Particle size and crystal structure was observed via FESEM images at 500,5000, and 10,000 times of magnification.

\section{Preparation of strontium aluminate powder}

Strontium aluminate powder used for this study emitted greenish-blue light at the dominant wavelength of $491.5 \mathrm{~nm}$. The powder was transferred to two plain test tubes with each at the weight of $0.005 \pm 0.001$ g. One of the tubes placed in a dark room to ensure no/ minimum exposure of light to prevent charging powder. The second tube was irradiated with $473 \mathrm{~nm}$ single longitudinal mode beam blue laser at a constant output of $100 \mathrm{~mW}$ for $\sim 15$ minutes. Laser was placed at focus distance $(\sim 16 \mathrm{~cm})$ when irradiating the powder. The irradiation was done with laser to ensure the powder charged at known constant power, light energy, and period of charging.

\section{Preparation of blood samples}

Blood samples of $3 \mathrm{ml}$ were collected randomly from a wide range of patients with unknown information on blood counts and patients' gender. The patients were generally declared fit outpatients at the age group of 20 years old to 70 years old. The EDTA blood sample was partitioned to three aliquots with $1 \mathrm{ml}$ on each tube. One of the aliquots served as control (untreated). The other two were centrifuged to separate blood plasma and RBCs which the plasma later mixed with strontium aluminate powder for interaction.

\section{Irradiation to blood plasma}

The centrifuged blood plasmas were mixed with two tubed strontium aluminate powders, respectively. One of the tubed powders emitted photons when interacting with blood plasma. At the same time, the second powders emitted no/minimum light when interacting with blood plasma. Both blood plasmas with powder content interacted for 5, 10, 15, and 20 minutes. Later, the plasmas were mixed back to their respective RBCs for interaction at $\sim 22$ minutes.

\section{Observation of RBCs morphology and absorbance spec-} trum

The morphology of RBCs was observed via an optical microscope at 40 times magnification after blood smearing with a thin film of streaked blood. Blood smearing was done by having a portion of blood dropped near the frosted end of a clean glass slide and second glass slide as a spreader. The absorbance of washed RBCs was measured using a UV-Visible spectrophotometer at the range of $300 \mathrm{~nm}$ to $800 \mathrm{~nm}$.

\section{Ethical consideration}

This study is ethically approved by Universiti Sains Malaysia Research Ethics Committee under the study code of USM/JEPeM/16060208.

\section{Results and discussion}

Optical and structural properties of strontium aluminate powder

The absorbance spectrum for strontium aluminate powder in Fig. 1 shows that it is able to absorb a wide range of spectrum from $200 \mathrm{~nm}$ to $800 \mathrm{~nm}$. The absorption appears to be highest at the peak at around $650 \mathrm{~nm}$.

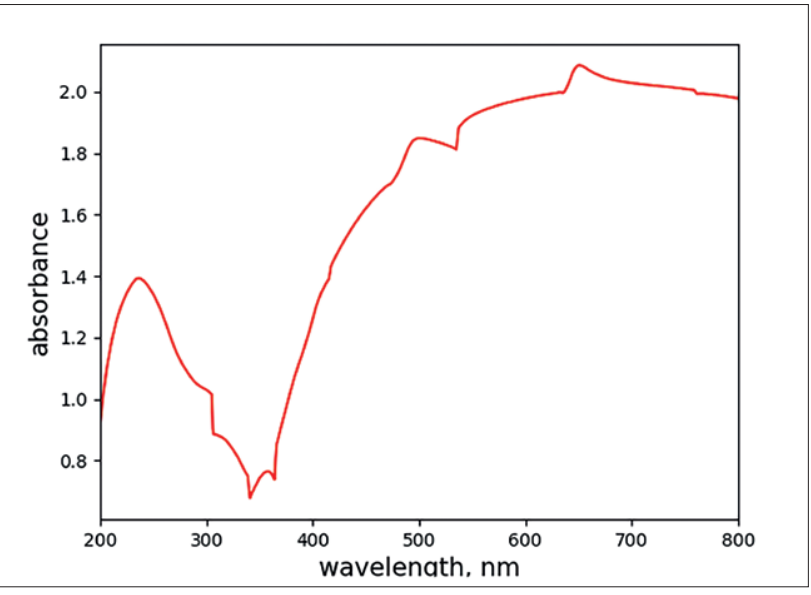

Fig. 1. Absorbance spectrum of strontium aluminate at wavelength of $200 \mathrm{~nm}$ to $800 \mathrm{~nm}$. The highest absorption located at around $650 \mathrm{~nm}$ and lowest at around $350 \mathrm{~nm}$

Рис. 1. Спектр поглощения алюмината стронция в интервале длин волн от 200 нм до 800 нм

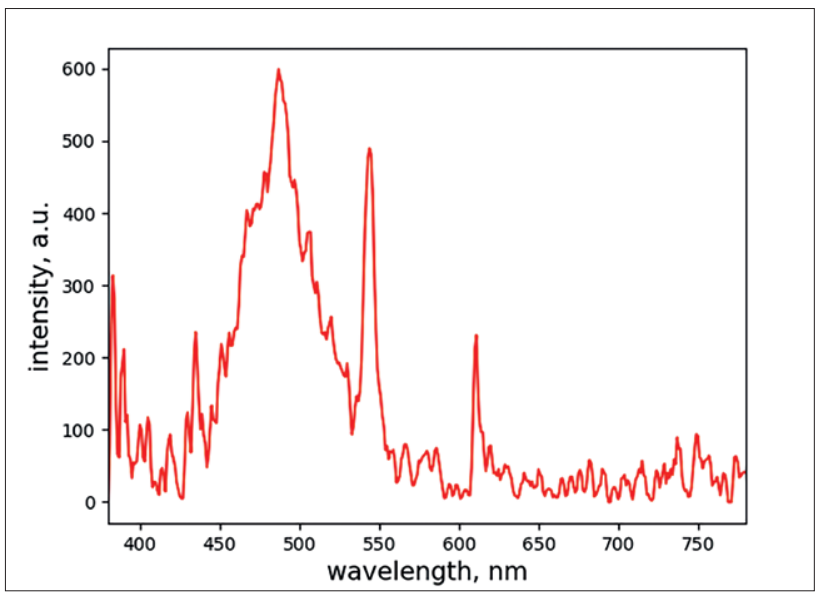

Fig. 2. Emission spectrum of strontium aluminate at wavelength of $380 \mathrm{~nm}$ to $780 \mathrm{~nm}$ after being irradiated with $473 \mathrm{~nm}$ laser. The dominant peak located at $491.5 \mathrm{~nm}$

Рис. 2. Спектр излучения алюмината стронция в интервале длин волн от 380 нм до 780 нм после облучения лазером при длине волны 473 нм 


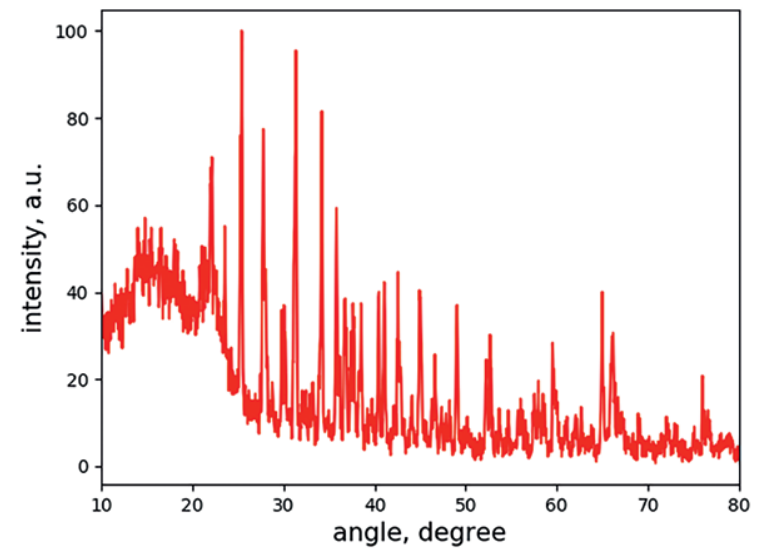

Fig. 3. XRD of strontium aluminate powder

Рис. 3. Рентгеноструктурный анализ порошка алюмината стронция

At the same time, the minimum absorption appears at wavelength around $350 \mathrm{~nm}$, which is represented with a trough. With the presence of the trough, it caused another appearance of a peak at a wavelength of around $250 \mathrm{~nm}$. Notice that the $250 \mathrm{~nm}$ peak's absorption is still not as high as other wavelengths ranging from $400 \mathrm{~nm}$ to $800 \mathrm{~nm}$.

Simultaneously, the emission spectrum of strontium aluminate powder has a dominant peak at $491.5 \mathrm{~nm}$, as shown in Fig. 2. Hence, with this known information, $473 \mathrm{~nm}$ laser was selected as the light source to charge strontium aluminate. This is due to higher light energy is required to allow strontium aluminate powder emitting $491.5 \mathrm{~nm}$ cyan (greenish-blue) light [19].
The XRD pattern of the powder is shown in Fig. 3. After comparing with database's (reference code: 00-052-1876) intensity peaks, it shows that the powder is potentially containing strontium, aluminum, and oxygen. In this pattern, the peaks can be indexed based on space group of PMMA with the number of 51 and orthorhombic crystal system. The orthorhombic system can be viewed at the FESEM images shown in Fig. 4a with 10,000 times of magnification. The crystal appears in pack with the size of approximately $4 \mu \mathrm{m}$. Fig. $4 \mathrm{~b}$ and $4 \mathrm{c}$ suggested that the particle size varies from $10 \mu \mathrm{m}$ to $50 \mu \mathrm{m}$ at cubic phase.

\section{Reaction of blood towards strontium aluminate}

Within the absorbance spectrum of RBCs, there are four obvious peaks along the spectrum at wavelength ranging from $300 \mathrm{~nm}$ to $800 \mathrm{~nm}$ as shown in Fig. 5. The first peak appears at $340 \mathrm{~nm}$, which indicates the maximum carbohydrate metabolism of blood caused by the structural changes of Nicotinamide Adenine Dinucleotide (NAD) into NADH and Nicotinamide Adenine Dinucleotide Phosphate (NADP) into NADPH through the reduction process. The other three peaks are visible at 414, 542, and $576 \mathrm{~nm}$ due to d-f transition of CO-oxyhemoglobin. The intensity of absorbance is linearly dependent by the concentration of solutes within blood samples after irradiation $[9,20,21]$.

As shown in Fig. 5, after the blood plasma interacted with the strontium aluminate powder, there is an obvious increment of absorbance intensity with respect to control blood, especially at $340 \mathrm{~nm}$. However, the intensity decrements when photons are emitted from powder, which acts as a light source. This has depicted a biphasic response (hormesis) given off by RBCs as the solely addi-

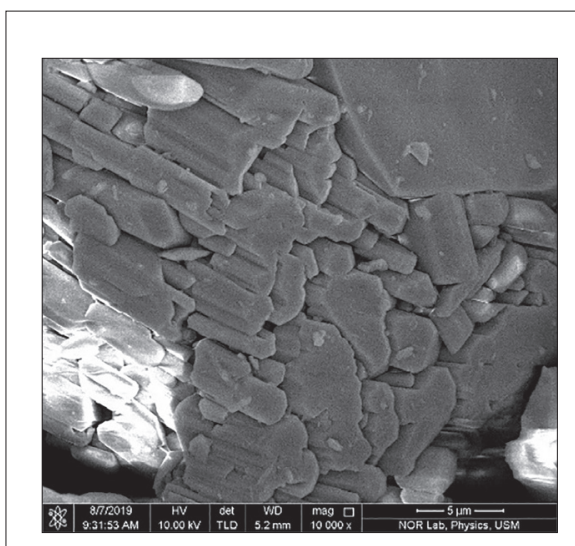

a

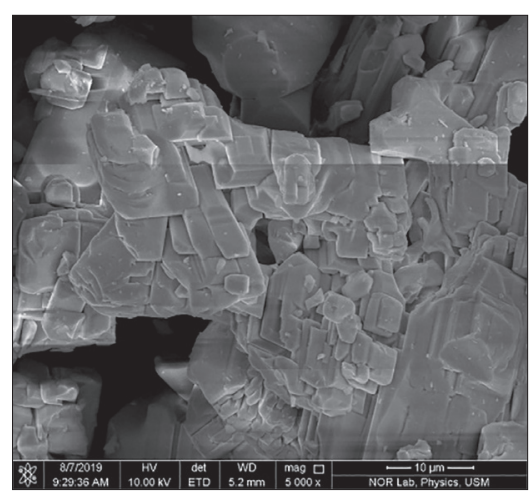

b

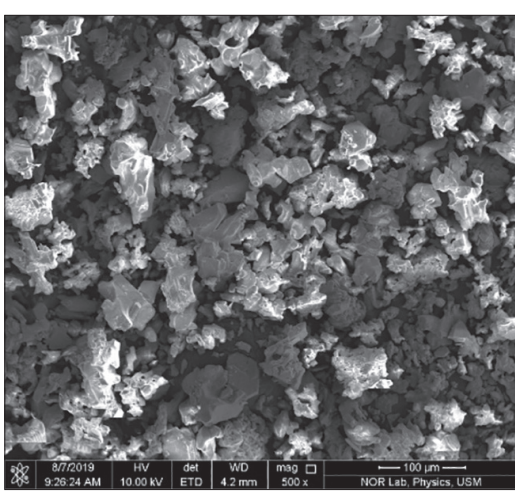

C

Fig. 4. FESEM images of strontium aluminate with difference magnification:

a - 10,000 times magnification;

b - 5,000 times magnification;

c - 500 times magnification

Pис. 4. Снимки алюмината стронция, полученные на сканирующем электронном микроскопе при различном увеличении: а - 10,000-кратное увеличение;

b - 5,000-кратное увеличение;

c - 500-кратное увеличение 


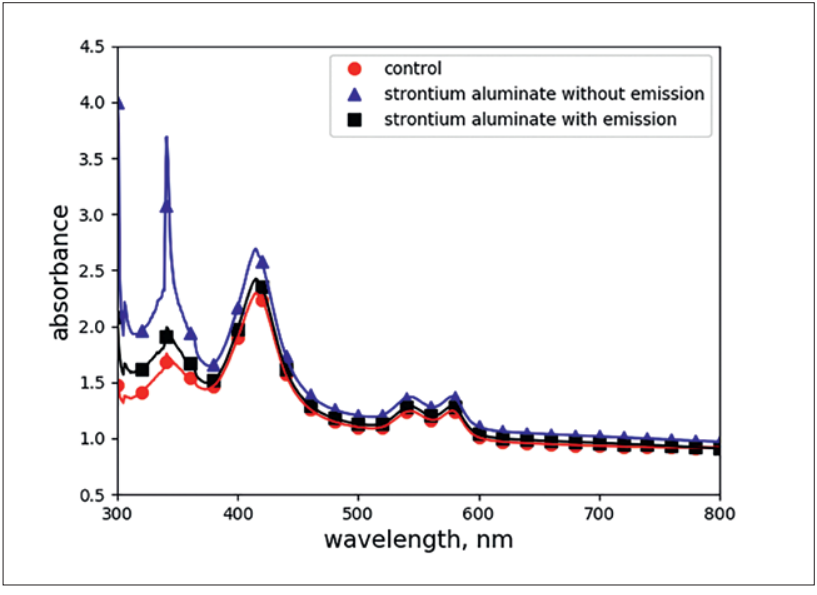

Fig. 5. Absorbance spectrum of RBCs at three conditions (control blood sample, blood sample with plasma interacted with no emission from strontium aluminate powder, and blood sample with plasma interacted with photon emission from powder) at the range of 300 to $800 \mathrm{~nm}$

Рис. 5. Спектр поглощения эритроцитов в трех условиях (контрольная проба крови, проба крови с плазмой, взаимодействующей с неизлучающим порошком алюмината стронция, и проба крови с плазмой, взаимодействующей с фосфоресцирующим порошком) в диапазоне от 300 до 800 нм

tion of powder, either photon emitting or not, changes the environment factor of blood [5-7]. The changes in intensity are associated with the variability of coenzyme in conjunction with echinocytes [22].

Shown in Fig. 6 is the morphology of RBCs with the presence of echinocytes labeled. The number of echinocytes increases along with the present powder and further increased as powder emitting photon. This suggested that the increment at $340 \mathrm{~nm}$ is due to the production of NADPH in preventing globin from denaturing [22]. Concurrently, a further increase of echinocytes de-

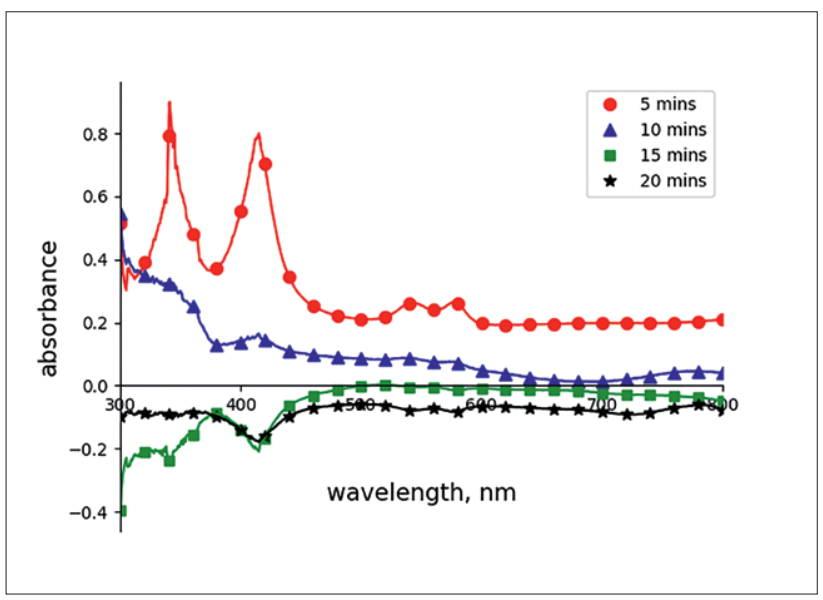

Fig. 7. Absorbance spectrum of RBCs after interacted with photon emitting strontium aluminate powder for $5,10,15$, and 20 minutes

Рис. 7. Спектр поглощения эритроцитов после взаимодействия с фосфоресцирующимм порошком алюмината стронция в течение 5, 10, 15 и 20 мин

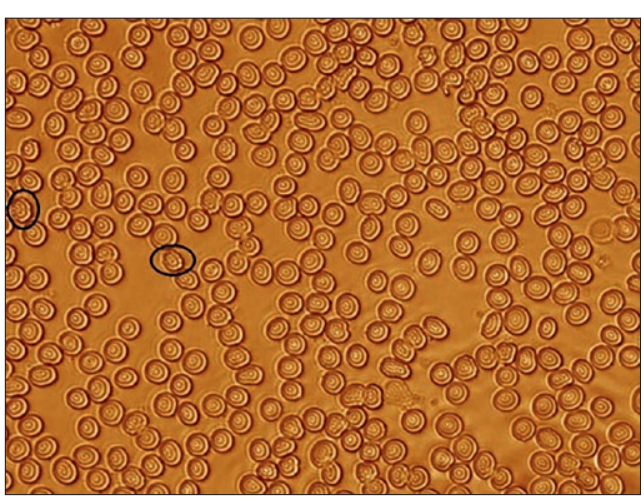

a

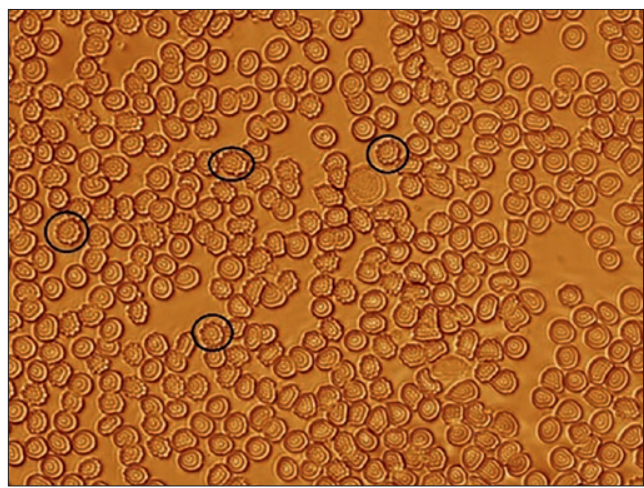

b

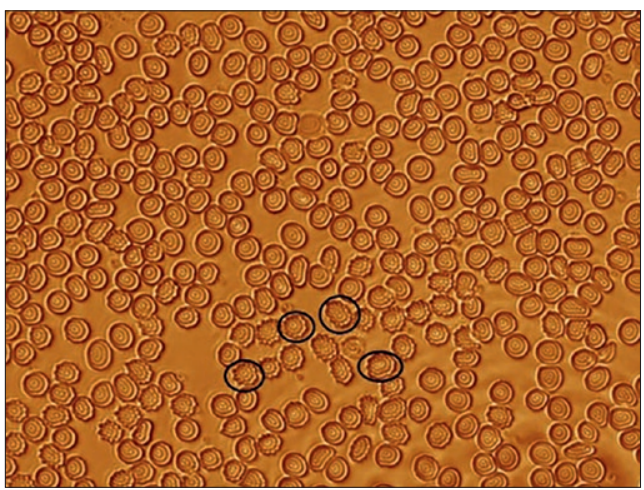

Fig. 6. RBCs morphology for control blood samples and blood samples that the blood plasma interacted with strontium aluminate powder (photon emitting and no photon emitting) for 5 minutes. Some presence of echinocytes are indicated with circles:

a - control blood samples;

b - blood plasma interacted with photon emitting strontium aluminate powder

c - blood plasma interacted with no photon emitting strontium aluminate powder

Рис. 6. Морфология эритроцитов для контрольных образцов крови и образцов крови после взаимодействия плазмы с порошком алюмината стронция:

a - контрольные образцы крови;

$\mathrm{b}$ - после взаимодействия плазмы крови с фосфоресцирующим порошком алюмината стронция;

c - после взаимодействия плазмы крови с неизлучающим порошком алюмината стронция 


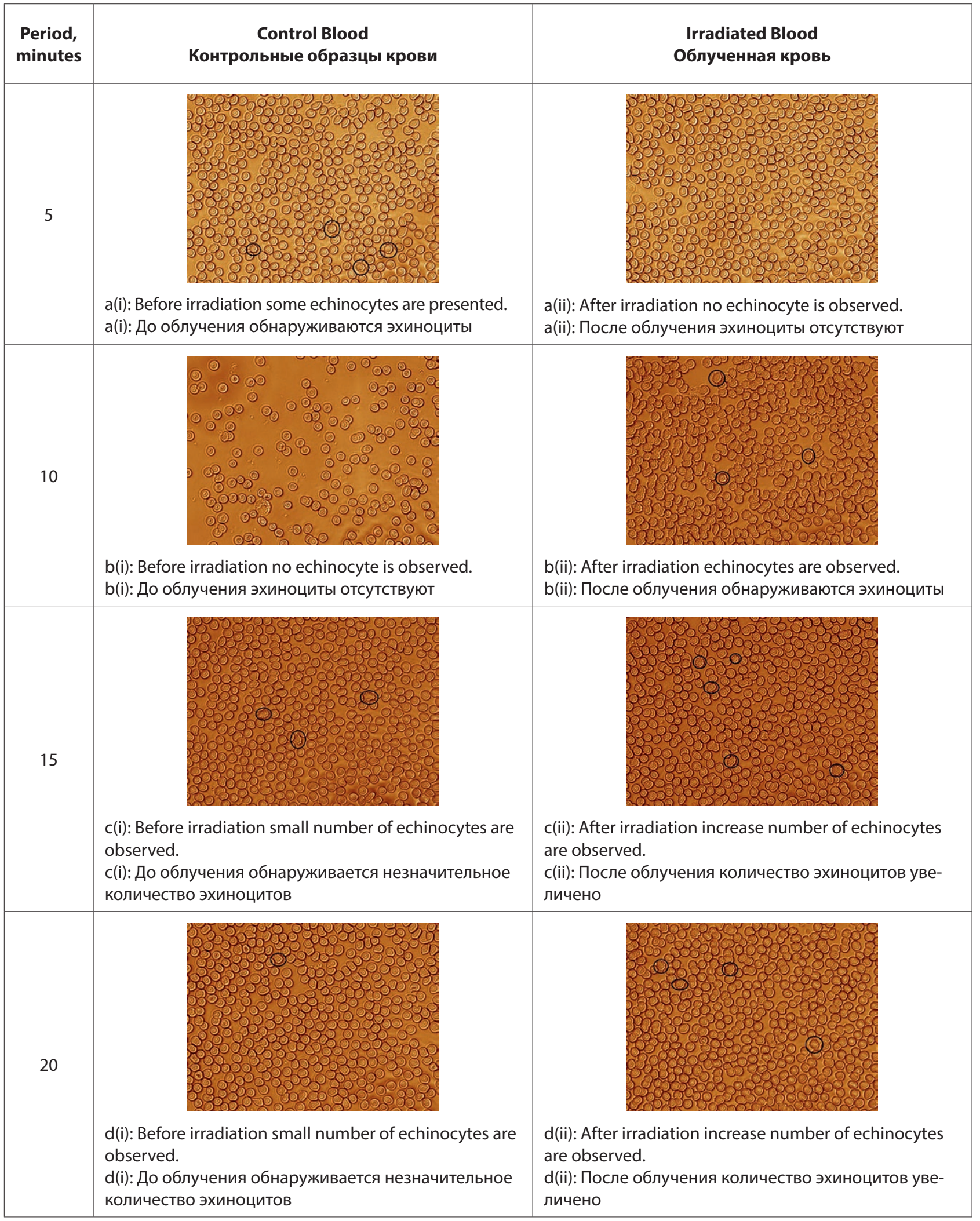

Fig. 8. RBCs morphology for control blood and blood, which has its plasma interact with photon emitting strontium aluminate. The interaction (irradiation) period is shown in the "Period" column with values of 5, 10, 15, and 20 minutes. Some echinocytes are indicated with circles

Рис. 8. Морфология эритроцитов для контроля крови и крови, в плазме которой происходит взаимодействие с испущенными алюминатом стронция фотонами. Период взаимодействия (облучения) показан в столбце “период”, который включает в себя 5, 10, 15 и 20 минут. Некоторые эхиноциты обозначены кружочками 


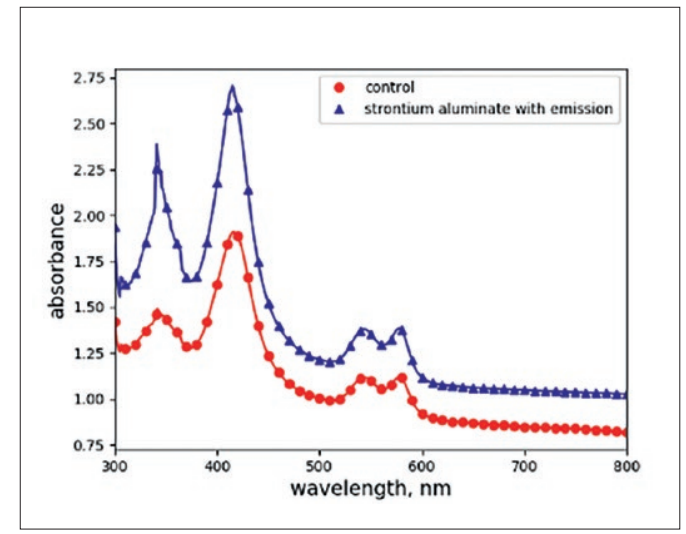

(a): Blood plasma irradiated for $\mathbf{5}$ minutes. Absorbance for irradiated blood has increased compare to the control blood. (а): Плазму крови облучали в течение 5 мин. Поглощение облученной крови увеличилось по сравнению с контрольной кровью

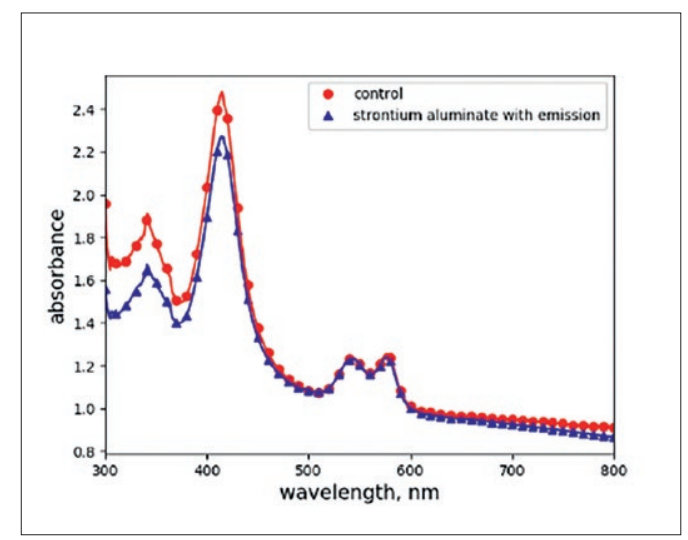

(c): Blood plasma irradiated for $\mathbf{1 5}$ minutes. Absorbance for irradiated blood has decreased compare to the control blood.

(c): Плазму крови облучали в течение 15 мин. Поглощение для облученной крови уменьшилось по сравнению с контрольной кровью.

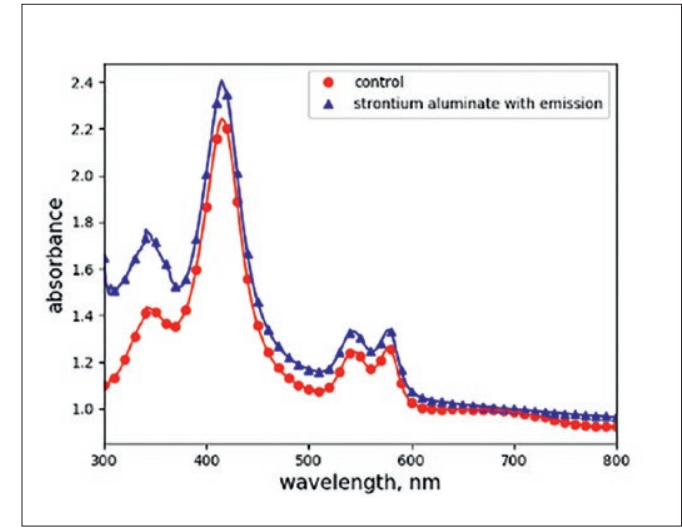

(b): Blood plasma irradiated for $\mathbf{1 0}$ minutes. Absorbance for irradiated blood has slightly increased compare to the control blood.

(b): Плазму крови облучали в течение 10 мин. Поглощение для облученной крови несколько увеличилось по сравнению с контрольной кровью.

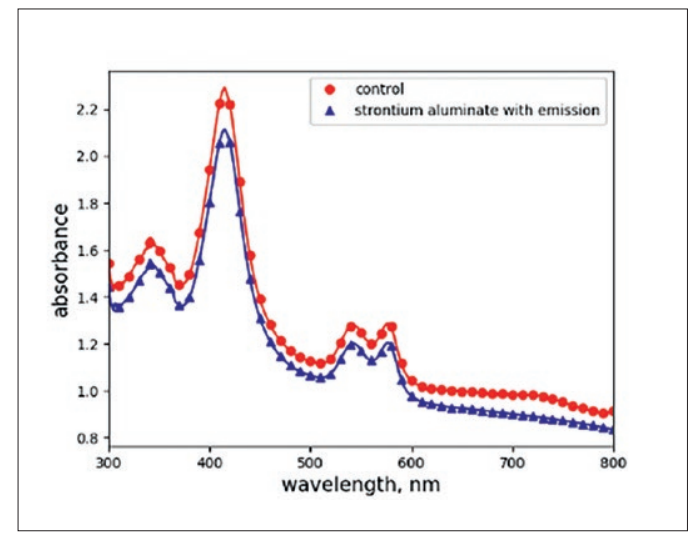

(d): Blood plasma irradiated for $\mathbf{2 0}$ minutes. Absorbance for irradiated blood has decreased compare to the control blood.

(d): Плазму крови облучали в течение 20 мин. Поглощение для облученной крови уменьшилось по сравнению с контрольной кровью.

Fig. 9. Absorbance spectrum of RBCs for irradiated blood samples and control blood samples. The period of irradiation is stated at each Fig.

Рис. 9. Спектр поглощения эритроцитов для облученных образцов крови и контрольных образцов крови. Период облучения указан на каждом графике

creases the production of ATP [23]. Notice that the effect is observable even though only blood plasma is irradiated. This phenomenon is known as the bystander effect, in which the effect towards RBCs is induced by the changes of blood plasma (medium) after interaction with the powder [24].

Analyzation of absorbance and morphology of RBCs

Shown in Fig. 7 is the absorbance after the blood plasma has been irradiated by photon emitted from strontium aluminate powder for 5, 10, 15, and 20 minutes. The irradiance of powder is kept at constant by having a constant amount in terms of weight and laser power when irradiated. The absorbance appears to be highest after 5 minutes of irradiation and starts to decrease beyond that. This relationship coincides with Arndt-Schulz model, which suggests 5 minutes irradiation is the optimum for stimulation, with the inhibition after 5 minutes.

Based on the RBCs morphology between control blood and irradiated blood, the chemical changes can 
be studied. From the morphologies shown in Fig. 8, the morphology has enhanced with the restoration of discocyte state from echinocyte. This restoration can normally be done by in vitro suspending normal plasma, albumin, glucose, gelatin, polyvinyl-pyrrolidine and fixatives such as glutaraldehyde, osmic acid, etc. [25]. This enhancement is observed after 5 minutes of irradiation. However, denaturing occurs after 10 minutes irradiation and beyond.

The presence of echinocytes suggested the decrease of ATP caused by loss of water and potassium in RBCs. Hence, with the improvement of morphology (decrease number of echinocytes) the ATP would be increased [22, 23]. However, at 10 minutes irradiation the denaturing may have underwent the production of NADPH to reduce oxidized glutathione into glutathione with the aim of preventing the denaturing of globin within RBCs [22]. The variation of solutes is shown in conjunction with the absorbance spectrum, as displayed in Fig. 7 [21-23]. The absorbance spectrum in Fig. 7 is obtained by having the subtraction between the irradiated blood's absorbance spectrum (abs $s_{i r}$ ) with control blood's absorbance spectrum ( $\left.a b s_{\text {control }}\right)$. This is done to examine the sole effect of photon towards blood by eliminating the possible inherent illness from the patients [26]. The equation representation is as followed: $a b s_{\text {irr }}-a b s_{\text {control }}$ Individual absorbance spectrums are shown in Fig. 9 for further reference. Notice that the decrease in $a b s_{\text {irr }}$ with $a b s_{\text {control }}$ as a reference that results in a negative absorbance shown in Fig. 7.

\section{ЛИТЕРАТУРА}

1. Le Duff F. et al. 308-nm excimer lamp vs. 308-nm excimer laser for treating vitiligo: A randomized study // Br. J. Dermatol. - 2010. Vol. 163, № 1. - P. 188-192.

2. Seidman D.S. et al. A prospective randomized controlled study of phototherapy using blue and blue-green light-emitting devices, and conventional halogen-quartz phototherapy // J. Perinatol. 2003. - Vol. 23, № 2. - P. 123-127.

3. Chung $\mathrm{H}$. et al. The nuts and bolts of low-level laser (Light) therapy // Ann. Biomed. Eng. - 2012. - Vol. 40, № 2. - P. 516-533.

4. De Freitas L.F., Hamblin M.R. Proposed Mechanisms of Photobiomodulation or Low-Level Light Therapy // IEEE J. Sel. ToP. Quantum Electron. - 2016. - Vol. 22, № 3. - P. 1-37.

5. Hamblin M.R. et al. Biphasic dose response in low level light therapy - an update // Dose-Response. - 2011. - Vol. 9, № 4. P. 602-618.

6. Mattson M.P. Hormesis defined // Ageing Res. Rev. - 2008. - Vol. 7, № 1. - P. 1-7.

7. Sommer A.P. et al. Biostimulatory Windows in Low-Intensity Laser Activation: Lasers, Scanners, and NASA's Light-Emitting Diode Array System // J. Clin. Laser Med. Surg. - 2002. - Vol. 19, № 1. P. 29-33.

8. 8Chen $\mathrm{H}$. et al. Quantum dot light emitting devices for photomedical applications // J. Soc. Inf. Disp. - 2017. - Vol. 25, № 3. - P. 177-184.

9. Mohd Fuad S.S., Suardi N., Mustafa I.S. In Vitro UV-Visible Spectroscopy Study of Yellow Laser Irradiation on Human Blood // J. Phys. Conf. Ser. - 2018. - Vol. 995, № 1.

\section{Conclusion}

There is an obvious effect on blood using solely phosphorescent powder as light source for phototherapy. Even though the presence of phosphorescent powder changes the environment factor of blood, which induces the blood to respond with a process known as hormesis; photons have also played a role in changing the environment factor, as shown in section 3.2 Reaction of blood towards strontium aluminate. The results show that the optimum period of irradiation is 5 minutes with the improvement in RBCs morphology and increment in RBCs absorbance. Irradiation of 10 minutes and beyond induces inhibition of RBCs with a deterioration of morphology and decrement of absorbance. Bystander effect is observed in this study as RBCs are affected, although only blood plasma is irradiated. For future improvement, it is recommended to introduce magnetic-organic phosphorescent material with manipulatable photon emission for in-vivo usage. With this ideology, the material can be magnetically localized at the region of interest within the body, and can later carry out phototherapy. The controllable photon emission is integrated to avoid any unnecessary irradiation at the unintended area during treatment.

\section{Acknowledgement}

The authors would like to thank Wellness Center Universiti Sains Malaysia for their support in providing the blood samples for the research. Authors also wish to acknowledge Fundamental Research Grants (FRGS/203.PFIZIK.6711598) for the grant.

\section{REFERENCES}

1. Le Duff F. et al. 308-nm excimer lamp vs. 308-nm excimer laser for treating vitiligo: A randomized study, Br. J. Dermatol, 2010, vol. 163 , № 1, pp. 188-192.

2. Seidman D.S. et al. A prospective randomized controlled study of phototherapy using blue and blue-green light-emitting devices, and conventional halogen-quartz phototherapy, J. Perinatol, 2003, vol. 23, № 2, pp. 123-127.

3. Chung $\mathrm{H}$. et al. The nuts and bolts of low-level laser (Light) therapy, Ann. Biomed. Eng, 2012, vol. 40, № 2, pp. 516-533.

4. De Freitas L.F., Hamblin M.R. Proposed Mechanisms of Photobiomodulation or Low-Level Light Therapy, IEEE J. Sel. ToP. Quantum Electron, 2016, vol. 22, № 3, pp. 1-37.

5. Hamblin M.R. et al. Biphasic dose response in low level light therapy - an update, Dose-Response, 2011, vol. 9, № 4, pp. 602-618.

6. Mattson M.P. Hormesis defined, Ageing Res. Rev, 2008, vol. 7, № 1 , pp. 1-7.

7. Sommer A.P. et al. Biostimulatory Windows in Low-Intensity Laser Activation: Lasers, Scanners, and NASA's Light-Emitting Diode Array System, J. Clin. Laser Med. Surg, 2002, vol. 19, № 1, pp. 29-33.

8. Chen H. et al. Quantum dot light emitting devices for photomedical applications, J. Soc. Inf. Disp, 2017, vol. 25, № 3, pp. 177-184.

9. Mohd Fuad S.S., Suardi N., Mustafa I.S. In Vitro UV-Visible Spectroscopy Study of Yellow Laser Irradiation on Human Blood, J. Phys. Conf. Ser, 2018, vol. 995, № 1.

10. Kujawa J. et al. Effect of Low-Intensity $\left(3.75-25 \mathrm{~J} / \mathrm{cm}^{\wedge} 2\right)$ NearInfrared $(810 \mathrm{~nm})$ Laser Radiation on Red Blood Cell ATPase 
10. Kujawa J. et al. Effect of Low-Intensity $\left(3.75-25 \mathrm{~J} / \mathrm{cm}^{\wedge} 2\right)$ NearInfrared $(810 \mathrm{~nm})$ Laser Radiation on Red Blood Cell ATPase Activities and Membrane Structure // J. Clin. Laser Med. Surg. 2004. - Vol. 22, № 2. - P. 111-117.

11. Al Musawi M.S. et al. Erythrocyte sedimentation rate of human blood exposed to low-level laser // Lasers Med. Sci. Lasers in Medical Science. - 2016. - Vol. 31, № 6. - P. 1195-1201.

12. Mitrofanis J. et al. The potential of light therapy in Parkinson's disease // ChronoPhysiology Ther. - 2014. № February.

13. Shaw V.E. et al. Neuroprotection of midbrain dopaminergic cells in MPTP-treated mice after near-infrared light treatment // J. ComP. Neurol. - 2010. - Vol. 518, № 1. - P. 25-40.

14. Hamblin M.R. Shining light on the head: Photobiomodulation for brain disorders // BBA Clin. The Author. - 2016. - Vol. 6. - P. $113-$ 124.

15. Lapchak P.A., Wei J., Zivin J.A. Transcranial Infrared Laser Therapy Improves Clinical Rating Scores After Embolic Strokes in Rabbits. 2004. - P. 1985-1988.

16. Sadeh M. et al. Low-Level Laser Therapy Applied Transcranially to Rats After Induction of Stroke Significantly Reduces Long-Term. 2006. - P. 2620-2624.

17. Jagdeo J.R. et al. Transcranial Red and Near Infrared Light Transmission in a Cadaveric Model // PLoS One. - 2012. - Vol. 7, № 10. - P. 1-10.

18. Tedford C.E. et al. Quantitative analysis of transcranial and intraparenchymal lightpenetration in humancadaverbraintissue// Lasers Surg. Med. - 2015. - Vol. 47, № 4. - P. 312-322.

19. Baryshnikov G., Minaev B., Ågren H. Theory and Calculation of the Phosphorescence Phenomenon // Chem. Rev. - 2017. - Vol. 117, № 9. - P. 6500-6537.

20. Mattley Y. et al. Blood characterization using UV/vis spectroscopy. 1995. - Vol. 2388. - P. 462-470.

21. Soltani S., Ojaghi A., Robles F.E. Deep UV dispersion and absorption spectroscopy of biomolecules // Biomed. Opt. Express. - 2019. Vol. 10, № 2. - P. 487.

22. Brown K.A. Erythrocyte metabolism and enzyme defects // Lab. Med. - 1996. - Vol. 27, № 5. - P. 329-333.

23. Lynch E.C. Peripheral Blood Smear- Edward Lynch // Clinical Methods: The History, Physical, and Laboratory Examiniations. 3rd ed. Butterworth Publishers. - 1990. - P. 732-734.

24. Paul A. et al. The bystander effect in optically trapped red blood cells due to plasmodium falciparum infection // Trans. R. Soc. TroP. Med. Hyg. - 2013. - Vol. 107, № 4. - P. 220-223.

25. Marcel B., Lawrence S. L. The Discocyte-Echinocyte Equilibrium of the Normal and Pathologic Red Cell. - 1970. - Vol. 36, № 3. P. 399-404.

26. Suardi N. et al. Effect of visible laser light on ATP level of anaemic red blood cell // J. Photochem. Photobiol. B Biol. - 2016. - Vol. 162. - P. 703-706.
Activities and Membrane Structure, J. Clin. Laser Med. Surg, 2004, vol. 22, № 2, pp. 111-117.

11. Al Musawi M.S. et al. Erythrocyte sedimentation rate of human blood exposed to low-level laser, Lasers Med. Sci. Lasers in Medical Science, 2016, vol. 31, № 6, pp. 1195-1201.

12. Mitrofanis J. et al. The potential of light therapy in Parkinson's disease, ChronoPhysiology Ther, 2014, February.

13. Shaw V.E. et al. Neuroprotection of midbrain dopaminergic cells in MPTP-treated mice after near-infrared light treatment, $J$. ComP. Neurol, 2010, vol. 518, № 1, pp. 25-40.

14. Hamblin M.R. Shining light on the head: Photobiomodulation for brain disorders, BBA Clin. The Author, 2016, vol. 6, pp. 113-124.

15. Lapchak P.A., Wei J., Zivin J.A. Transcranial Infrared Laser Therapy Improves Clinical Rating Scores After Embolic Strokes in Rabbits, 2004, pp. 1985-1988.

16. Sadeh M. et al. Low-Level Laser Therapy Applied Transcranially to Rats After Induction of Stroke Significantly Reduces Long-Term 2006, pp. 2620-2624.

17. Jagdeo J.R. et al. Transcranial Red and Near Infrared Light Transmission in a Cadaveric Model, PLoS One, 2012, vol. 7, № 10, pp. 1-10.

18. Tedford C.E. et al. Quantitative analysis of transcranial and intraparenchymal light penetration in human cadaver brain tissue, Lasers Surg. Med, 2015, vol. 47, № 4, pp. 312-322.

19. Baryshnikov G., Minaev B., Ågren H. Theory and Calculation of the Phosphorescence Phenomenon, Chem. Rev, 2017, vol. 117, № 9, pp. 6500-6537.

20. Mattley Y. et al. Blood characterization using UV/vis spectroscopy, 1995, vol. 2388, pp. 462-470.

21. Soltani S., Ojaghi A., Robles F.E. Deep UV dispersion and absorption spectroscopy of biomolecules, Biomed. Opt. Express, 2019, vol. 10, № 2, pp. 487.

22. Brown K.A. Erythrocyte metabolism and enzyme defects, Lab. Med, 1996, vol. 27, № 5, pp. 329-333.

23. Lynch E.C. Peripheral Blood Smear- Edward Lynch, Clinical Methods: The History, Physical, and Laboratory Examiniations. 3rd ed. Butterworth Publishers, 1990, pp. 732-734.

24. Paul A. et al. The bystander effect in optically trapped red blood cells due to plasmodium falciparum infection, Trans. $R$. Soc TroP. Med. Hyg, 2013,vol. 107, № 4, pp. 220-223.

25. Marcel B., Lawrence S. L. The Discocyte-Echinocyte Equilibrium of the Normal and Pathologic Red Cell, 1970., vol. 36, № 3, pp. 399404.

26. Suardi N. et al. Effect of visible laser light on ATP level of anaemic red blood cell, J. Photochem. Photobiol. B Biol, 2016, vol. 162, pp. 703-706. 